\title{
Coping with Unresolvable Uncertainty: A Situational Analysis of Regenerative Medicine Venturing Activity
}

\begin{abstract}
Acquiring resources, such as knowledge, is a fundamental entrepreneurial task during venture development. However, high levels of uncertainty challenge resource identification and access, hence collaboration and knowledge exchange mechanisms are valuable. During high levels of perceived environmental uncertainty, entrepreneurs and new ventures are required to develop coping strategies to ensure venture formation and growth. Yet, entrepreneurial coping during high uncertainty is an understudied process. The regenerative medicine (RM) sector represents a unique context for studying entrepreneurial activity under high levels of uncertainty. We consider how uncertainty in RM venturing affects entrepreneurial behavior. Informed by long-form, narrative interviews, we propose a process model of RM venturing linking uncertainty, university culture, collaboration and coping. The use of selective revealing in RM venturing, and the effect of different coping responses on resource assembly and collaborative knowledge, is considered. Our findings advance theories of venture development during high uncertainty.
\end{abstract}

Keywords: uncertainty, coping, collaboration, knowledge, venturing, entrepreneur 


\section{Introduction}

In high uncertainty environments, entrepreneurs struggle to identify which resources to assemble and coordinate (Alvarez and Barney, 2005). New ventures must acquire key resources such as finance, knowledge and partnerships (Jarillo, 1989), but high levels of perceived environmental uncertainty (PEU) inhibit entrepreneurial behavior and sense making (Milliken, 1987). As such, collaboration and knowledge exchange mechanisms become especially valuable for the development of deep capabilities needed to exploit opportunities (Powell et al, 1996; George et al, 2008). When PEU is high, entrepreneurs and ventures must develop coping mechanisms to avoid paralysis and ensure venture formation and growth. Despite important implications for theories of entrepreneurial behavior and venture growth, the development of entrepreneurial coping strategies under high uncertainty has not been rigorously studied.

The regenerative medicine $(\mathrm{RM})$ sector represents a fruitful context for studying entrepreneurial activity under extremely high levels of PEU. RM research, which often involves the use of stem cells, is "the process of creating living, functional tissues to repair or replace tissue or organ function lost due to age, disease, damage or congenital defects" (NIH, 2006). RM is expected to address unmet clinical needs, enhance human health, and generate significant commercial benefits. However, extremely high levels of uncertainty have limited the development of the RM industry. Despite active research clusters in numerous geographic locations, including the UK (Jennifer, 2011), venturing has been slow and the venturing process unclear.

Venture development in RM has not been well studied. We study how uncertainty affects entrepreneurial behavior through a situational analysis of resource assembly in RM venturing activity. In particular, we ask two questions. First, what are the unique aspects of resource assembly in RM venturing? Second, how does knowledge, accessed through collaborations and 
networks, affect RM venture formation and growth? Informed by a pilot survey and long-form narrative interviews, we propose a RM venturing process model. The results point towards the development of specific coping strategies to address high levels of PEU. These are linked to the development of collaborative knowledge during venture formation and growth. Our study opens new research directions linking entrepreneurial sense-making to venture growth when uncertainty cannot be resolved by information gathering or analysis. It specifically builds on recent investigations on selective revealing as an alterative form of collaboration (Alexy et al, 2013).

\section{Contributions}

This research makes three contributions to the scholarly literature. First, we investigate entrepreneurial activity in an understudied field characterized by unusually high uncertainty. Second, this study advances theories of venture development by proposing a preliminary model linking uncertainty, collaboration and coping. Third, we extend university-industry scholarship by showing the link between university culture and venture coping strategies.

Our research also provides important practical contributions to RM practitioners and technology transfer offices (TTOs).

\section{Venturing in the Regenerative Medicine Field}

The RM industry faces complex political and social forces, uncertain regulatory frameworks, unresolved intellectual property (IP) rights issues, and untested production and distribution systems (Hogle, forthcoming 2014). The investment and infrastructure requirements of RM commercialization have favored entrepreneurial activities with explicit links to university research programs. These ties, along with the complex technological innovations of RM research and the uncertain venturing process, create numerous development challenges for RM 
entrepreneurs.

The dependency on the larger institution may create resource assembly challenges for new technology ventures (Powell et al, 1996). These firms must operate with little or no slack in their resource pool, limiting product-market and business model exploration and testing (George, 2005; Bock et al, 2012). The perception of high risk in RM venturing has limited investments by venture capitalists (VCs) and pharmaceutical companies. This has created a capabilities gap between RM innovation and commercialization (Mittra and Tait, 2012). Entrepreneurs may compensate for resource scarcity by accessing social networks to legitimize organizational narratives and access knowledge and financial resources (Aldrich and Martinez, 2001; Lounsbury and Glynn, 2001). We expect that RM entrepreneurs and ventures will rely on collaboration and networks to access resources, including knowledge, in order to exploit opportunities. The processes, however, have not been carefully investigated within the context of RM venturing activity.

\section{Methods}

To explore sense-making and behavioral processes, we utilize a primarily qualitative approach to better develop insights into socially constructed knowledge and events (Locke, 2001). A small pilot survey confirmed the relevance of key constructs, but the primary dataset consists of long-form, narrative interviews (McCracken, 1988).

\section{Data}

Information about the complete set of qualitative informants is provided in Table 1 . This includes role, informant type, organizational affiliation and location. 
Table 1 here

The lead author conducted face-to-face, long-form narrative interviews with informants between November 2012 and September 2013. Interviews were conducted in private facilities to prevent interruptions and ensure confidentiality. Informants were asked to tell their story of their participation in the commercialization of regenerative medicine innovation. Informants were given complete freedom to recount their narrative without interruption and with limited or no further direction. This narrative interview approach was utilized to minimize investigator bias, increase informant comfort and encourage informants to recount their own story in their own words, allowing them to focus on self-identified areas of interest. Legal and ethical controversies associated with RM require an especially sensitive approach to the collection of qualitative data. The open-ended, non-directed narrative approach helps to reduce staged responses and social desirability bias (Podsakoff et al, 2003). Informants were encouraged to talk until they felt that they had reached a self-determined conclusion. Following the informant-determined end of the main narrative, some informants were prompted to provide additional details on key areas of interest. Field notes were generated during and immediately after each interview to provide in situ interpretation to complement transcript coding. The duration of the interviews ranged from 16 minutes to 111 minutes, with the average length being approximately 60 minutes.

A small-scale pilot survey was utilized to confirm the relevance of key constructs and frame the coding of the narrative interviews. The survey was designed to elicit data on informant's perceptions of RM venturing. Survey questions included both closed and open-ended questions on facilitative and inhibitive factors to RM venturing activity. Question types and order were carefully considered to reduce common method biases (Podsakoff et al, 2003). The survey 
was pre-tested by administration to an RM industry expert and an academic scientist to ensure clarity of design and relevance of the questions (Fowler, 2009).

The lead author obtained information on target informants from Edinburgh BioQuarter, the commercialization arm of research output from the College of Medicine and Veterinary Medicine at The University of Edinburgh. Informants were selected based on direct involvement in the commercialization of RM in one of the following 4 categories: 1) RM entrepreneurs, 2) academic scientists, 3) RM/life science support entities, 4) RM companies. We excluded for-profit third party support firms such as consultancies. We also excluded full-time students, even those with significant entrepreneurial intent. This ensured efficient and effective saturation of categories, providing sufficient data to account for all aspects of the phenomenon (Morse et al, 2002). Informants were not provided detailed information about the interview to prevent prejudicial preparation of information or materials. The final dataset includes 23 long-form narratives.

\section{Procedures}

Coding of the qualitative interviews was informed by the results of the pilot survey. Survey informants were selected from the RM informant target list and e-mailed regarding their participation. We invited 26 individuals to participate in the survey and received 15 responses, which represents a 58\% success rate. Referrals by first-wave respondents to additional industry participants generated 7 additional responses. Therefore, a total of 22 responses were utilized in the pilot survey analysis. Since the pilot survey data was used primarily to inform the qualitative interview coding, we report only simple descriptive statistics.

Analysis of the RM venturing interview narratives was informed by grounded theory (Strauss and Corbin, 1990). First-order codes were generated via open-ended coding of the transcripts. These were triangulated against the results of the pilot survey to identify overlap and 
gaps. Then, through a cycle of inductive and deductive reasoning, theoretical categories representing theoretical groupings of the first-order codes were identified. Finally, theoretical categories were organized into aggregate theoretical dimensions.

\section{Findings}

We first present the findings of the online pilot survey. Following this, we discuss the narrative interview findings.

\section{Online pilot survey findings}

Pilot survey findings are presented in Figure 1. Most informants agreed (45.45\%) or strongly agreed (31.82\%) that RM commercialization is challenging due to resource constraints, and that collaborations are required for commercialization. Informants agreed (45.45\%) or strongly agreed $(27.27 \%)$ that collaboration with academic institutions is a requirement for commercialization. Similarly, most informants agreed $(40.91 \%)$ or strongly agreed $(36.36 \%)$ that collaboration with hospitals is necessary for commercialization. However, the majority of informants disagreed $(50.00 \%)$ that collaborations with "big pharma" (large pharmaceutical companies) are required for RM commercialization. Most informants agreed (45.45\%) that collaborations provide RM ventures with access to resources and agreed (63.64\%) that collaborations enabled capabilities to be acquired. Furthermore, informants agreed (54.55\%) or strongly agreed (36.36\%) that knowledge is exchanged during collaborations and disagreed (40.91\%) with the statement that RM collaborations were difficult to manage. Informants also disagreed $(36.36 \%)$ or neither agreed/disagreed $(31.82 \%)$ that RM collaborations often fail to deliver. Most informants agreed (31.82\%) that governmental funding could be accessed for commercialization. However, there were differing views as to whether $\mathrm{VC}$ funding could be 
accessed, with $31.82 \%$ of informants being in agreement and $31.82 \%$ being in disagreement. There was high agreement (63.64\%) amongst informants that unresolved regulatory issues are affecting RM commercialization. Also, most informants agreed (36.36\%) that manufacturing, distribution and scale-up uncertainties are affecting RM commercialization. Most informants agreed $(40.91 \%)$ that unrealistic timeframes are set for RM commercialization, and most agreed $(31.82 \%)$ or strongly agreed $(31.82 \%)$ that RM business models are unknown and unproven.

Figure 1 here

\section{Narrative interview findings}

Output of the interview findings is presented in Table 2, utilizing a multi-level data structure (Walsh and Bartunek, 2011). The first column of the table shows the prevalence (\%) of first-order codes within the total (T) 23 interviews. The table also highlights the prevalence (\%) of first-order codes for each category, which includes interviews with 6 entrepreneurs (E), interviews with 3 academics (A), interviews with 12 support entities (SE) and interviews with 2 $\mathrm{RM}$ companies (RC). We provide further discussion on first-order codes, theoretical categories and theoretical dimensions. Illustrative examples of first-order codes and theoretical categories are presented in Table 3.

Table 2 here

We review the theoretical dimensions revealed by the data and note specific examples to highlight findings and relevance.

Perceived environmental uncertainty (PEU). Our data shows high levels of PEU surrounding RM venturing. In consideration of Milliken's (1987) typology of uncertainty, RM 
ventures face high levels of state, effect and response uncertainties. In particular, given the high levels of environmental unpredictability, RM ventures face higher levels of state uncertainty. Informants consistently reported high levels of funding uncertainties, discussing the difficulties in securing funding for commercialization purposes. This is illustrated in example A in Table 3. RM venturing requires this funding gap or "valley of death" between stem cell discovery and translation to be bridged. Yet, achieving this is problematic at present, since RM venturing generally exceeds current investor timeframes and investment limits. Nevertheless, example B illustrates how conditional approval could be implemented in order to ease the funding gap. This provides ventures with access to the market prior to obtaining comprehensive data on safety and efficacy, but with the provision that more data is provided in the near future.

High levels of uncertainty also surround manufacturing, scale-up and distribution, as highlighted in example $\mathrm{C}$. This is consistent with prior research conducted on RM business models, which highlighted the problems faced by a bio-artificial liver device venture in distributing their product due to unavailable cryogenic solutions (Mastroeni et al, 2012). As such, we see in example $\mathrm{D}$ that to overcome distribution uncertainties, more localized RM treatments will be required where the patient travels to the site of production.

RM ventures also face high levels of regulatory uncertainty, especially unresolved IP rights issues, which is illustrated in example E. Legislative changes regarding the use of human embryonic stem cells (hESCs) has resulted in the shift to induced pluripotent stem cells (iPSC) but has required ventures to adapt their business model as a consequence. Whilst iPSC are seen as being more ethically acceptable, ethical uncertainties still surround the RM sector. Furthermore, scientific shifts are likely because stem cell science is still in its infancy.

It would appear that ventures focusing on tools or diagnostics are the most viable. This is because the financial resources required for commercialization of tools or diagnostics is 
significantly lower than the financial resources required to commercialize therapeutics. Example $\mathrm{F}$ in Table 3 illustrates this. However, despite tools or diagnostic ventures being the most viable in the short-term, given the current uncertainty within the RM sector, young RM tools or diagnostic ventures are likely to face downstream uncertainties such as reimbursement uncertainties, as confirmed in example G.

Coupled with these uncertainties are high levels of risk, which results in investor skepticism (Giebel, 2005). Risk was consistently discussed, with the suggestion that China and the US has different perceptions of risk in comparison to the UK. In a slightly different context, entrepreneurs discussed risk in terms of the personal risk that they face in financing their venture, as illustrated in example $H$. In contrast, when financial resources were obtained through governmental bodies, without this funding having to be matched or offered on a loan basis, risk was mitigated for the entrepreneur or venture.

Many of the uncertainties discussed within the dataset are consistent with previous research (Plagnol et al, 2009). It is evident that some ventures are not fully committing to this sector and only deploying limited resources until uncertainty and risk are reduced. Therefore, if the sector is to see advancements in RM venturing, these uncertainties must be addressed. In achieving this, RM ventures are engaging in collaborations, legitimacy building and knowledge exchange mechanisms.

University entrepreneurial culture. RM venturing is primarily driven by university-led stem cell research. As such, university academic scientists may be expected to participate in commercialization activities. This requires the inventing entrepreneur to modify their roleidentity, shifting from a scientific orientation to a more market-driven approach (Jain et al, 2009). However, as illustrated in example I, this often creates conflicting pressures as academics are 
measured on research papers and grants, not commercialization outcomes. This tension could impact their motivation for commercialization (Ndonzuau et al, 2002; Etzkowitz, 1998).

Commercialization of university-led stem cell innovations will be influenced by the entrepreneurial culture embedded within the university and the TTO's policies and procedures (Degroof and Roberts, 2004; Di Gregorio and Shane, 2003). Clear TTO policies may enable greater levels of commercialization (Lockett et al, 2003). Policies rewarding academic entrepreneurial behavior and commercialization have been shown to result in greater levels of commercialization (Renault, 2006; Friedman and Silberman, 2003; Lach and Schankerman, 2004; Henrekson and Rosenberg, 2001). Furthermore, the business development capabilities of TTO staff can influence commercialization (Thursby and Kemp, 2002; Lockett and Wright, 2005). Some staff may lack the technical and entrepreneurial understanding that is required to commercialize stem cell science (Lockett et al, 2005), which is highlighted in example J. RM venturing will, therefore, ultimately depend on universities deinstitutionalizing their traditional academic culture and adopting a more commercially oriented and entrepreneurial one (Scott, 2001; Dacin et al, 2002).

Coping strategies. In order to address high levels of PEU, entrepreneurs or ventures will be required to engage in coping strategies (Milliken, 1987). Our findings show entrepreneurs and ventures engaging in collaborations and legitimacy building in order to address the high levels of PEU.

The majority of collaborations are taking place for resource assembly purposes and improving particular processes, as highlighted in examples $\mathrm{K}$ and $\mathrm{L}$ respectively. They also provide access to funding and can build the legitimacy of a particular venture. Collaborations with industry and academia appear to be the most dominant types of collaboration within the 
dataset. Collaborations with the National Health Service (NHS) are also vitally important for RM venturing, as they enable access to clinicians. However, gaining access to the NHS and forming a collaborative partnership is currently challenging, as illustrated in example M. Collaborations involving support entities provide ventures with access to executives with expertise in new venture development. They also facilitate in connecting ventures with investment communities. However, despite the benefits of collaborations, the costs associated with collaborations were evident, as shown in example N.

In addition to the role of collaboration in addressing the high levels of PEU, uncertainty reduction is also possible as a consequence of legitimacy building. When high amounts of uncertainty and controversy surround a novel technology, legitimization of this technology becomes essential and can result in ventures acquiring critical resources (Jain and George, 2007). Legitimacy building can be achieved through entrepreneurial narratives, resulting in the creation of new wealth (Lounsbury and Glynn, 2001; Martens et al, 2007). Entrepreneurial stories were evident within the dataset as a means of legitimacy building and serving to reduce uncertainty, as highlighted in example O. To enhance legitimacy ventures should protect their technology, widely publicize their technology and influence key stakeholders (Jain et al, 2009). Example P highlights the protection of stem cell research. Publicizing technology through raising awareness is documented in example Q. The influencing of key stakeholders is illustrated in example R.

Collaborative knowledge. Coping strategies impact on resource assembly and enable the access of knowledge for venture formation and growth. Research on absorptive capacity (Cohen and Levinthal, 1990; Zahra and George, 2002) and tacit knowledge suggests that the sophisticated, technological requirements of life science entrepreneurship make it unlikely that new ventures will possess sufficient internal knowledge and must, therefore, collaborate and 
engage in resource exchange mechanisms to become competitive. Our findings highlight the exchange of knowledge and communication between the various actors operating within the RM sector. Knowledge is accessed through collaborations and networks, as illustrated in examples S and $\mathrm{T}$ respectively. This can be especially valuable as it can enable capability development. This is supported in example $\mathrm{U}$, where we see knowledge being accessed via collaboration with a university in order to develop capabilities. Accessing knowledge through NHS collaborations is also shown to be particularly useful, as this can identify relevant disease areas and markets to target. This is highlighted in example V. Such knowledge exchange mechanisms can result in learning. However, informants did discuss the difficulties in exchanging knowledge due to the language differences between the various actors within the sector and due to the tacitness of RM knowledge. This is illustrated in example W.

Social networks have been suggested to be an important mechanism for the assembly of resources and in the creation and exchange of knowledge (Aldrich and Martinez, 2001; Ardichvili et al, 2002). Within the RM sector there are several life science communities that have been established, with the aim of ensuring successful RM venturing. The Scottish Stem Cell Network (SSCN) was formed in 2002 and was tasked with building a RM community and delivering RM commercialization. This network connected the scientific community and SME community, and served to bridge the gap between the different languages spoken by the various actors within the RM sector. SSCN closed in January 2012 due to the lack of further governmental backing. In its place the Cell Therapy Catapult was formed in London, which is funded by the UK government and is charged with growing the UK stem cell sector. This is to be achieved through the advancement of RM research and bridging the translational gap, resulting in commercialization. In addition, knowledge transfer networks have been established. The Health Knowledge Transfer Network is concerned with delivering innovation within the health sector, 
which includes the medical biotechnology, medical technology, diagnostics and pharmaceutical industries. They organize events and workshops where industry actors can meet in order to share ideas and gain access to potential collaborators. The network also acts as a facilitator for the identification of new sources of funding. In example $\mathrm{X}$ we show knowledge access via networks, which assists the assembly of financial resources

Venture development. Accessing knowledge through collaborations and networks can enable RM ventures to form and grow. During this venture development period, ventures may continue to engage in coping strategies, resulting in additional collaborative knowledge. However, RM venture development is challenged due to a lack of slack resources. Financial resources are fundamental for venture formation and growth (Cassar, 2004), yet our data shows that entrepreneurs and ventures struggle to acquire financial resources. Governmental funding appears to be available for basic scientific RM research and to progress RM research to phase one/two studies. However, access to funding for clinical stage research and to deliver this research to market is currently challenging, as illustrated in example Y. At present, entrepreneurs and early stage RM ventures are required to match governmental funding with their existing financial resources, which is difficult. This is shown in example Z.

Currently, RM business models are unknown and unproven. Since RM is an evolving sector, it is reasonable to expect that RM business models will differ from the dominant life science business models and, as a result of the highly uncertain environment, it is probable that RM business models may evolve through a trial-and-error process (Heirman and Clarysee, 2004; Loch et al, 2008; Costa and Levie, 2012). Business model evolution through trial-and-error was exemplified within the dataset. When complexity and uncertainty are high, ventures may run multiple parallel business models and select the best performing one (Loch et al, 2008), as 
illustrated in example AA. This example documents how a RM venture ran two separate business models due to the high levels of uncertainty surrounding the sector. One focused on RM services, whilst the other focused on a RM tools business model. It transpired that there was not the market demand for the service business model and, therefore, the tools business model was adopted. Informants also discussed uncertainty surrounding their own business model, in some cases discussing business model failure or changes to their current business model due to a lack of market demand. This highlights that RM business models cannot be predicted ex ante. Entrepreneurs discussed their desire to become players in the RM therapeutics market but due to the high uncertainties and costs of being involved in this market, all were prevented from operating in this space. However, example BB illustrates a venture that is combining a business model focusing on tools with the desire to develop cell-based therapeutics, which hints towards business model innovation (George and Bock, 2012). Although, it remains unclear whether this venture is truly innovating their business model because business model innovation requires a deep understanding of market trends and sufficient resources to direct towards novel opportunities (Bock et al, 2012; Johnson et al, 2008). Therefore, it appears from the dataset that RM ventures focusing on tools or diagnostics may have a clearer path to a viable business model than those focusing on therapeutics, as previously discussed.

Outcomes. Currently the economic impact of the entire RM market is estimated to be between $\$ 2-5$ billion, which is expected to exceed $\$ 11$ billion by 2020 , contributing to a substantial reduction in healthcare costs (Tait et al, 2011). University-led RM venturing has the potential to result in significant economic gains. However, it should not be forgotten that failure is an unavoidable aspect of any entrepreneurial venture and even if universities are successful in 
transferring their technology, they should not always expect the economic gains to accrue to their local area (Miner et al, 2001; Bock, 2012).

The economic impacts of university-led technology transfer can be significant but technologies emanating from the university, most often than not, will require vast amounts of investment and time in order to become commercially viable (Bock, 2012). Informants, especially RM support entities, were especially concerned with RM venturing positively impacting the local economic environment. However, there was some concern as to whether the local environment could retain this innovation. Furthermore, the immediate visible economic gains for RM are not always apparent, as benefits are not instantaneously observable, which can affect investment. Example CC illustrates this.

Despite the high uncertainty surrounding RM venturing, suggestions for the trajectory of the market were forthcoming. One entrepreneur suggested that ventures should collaborate with the NHS to enable widespread commercialization. This will provide access to clinicians who are best placed to offer suggestions on disease areas and indications. The disease areas to focus on should be "orphan" diseases, as taking an orphan drug to market requires less financial capital and is less time intensive. As such, orphan drugs could serve as the exemplar to the RM industry, providing greater confidence in the market and enabling further investment. Furthermore, NHS collaboration provides access to NHS patients and the opportunity for clinical trials to be conducted. This can provide gradual safety and efficacy data, and along with conditional approval, this could prevent the need for large-scale efficacy trials, which are highly expensive and currently hindering RM venturing. Another future scenario, as suggested by an academic scientist, views RM venturing initially relying on the use of regenerative tools and technologies in drug screening. Over the next ten years, the industry will begin to see bespoke RM therapies as processing costs reduce. This could involve cells being taken from a patient, grown up in culture 
and then introduced back into the patient in order to repair the degenerative tissue or organ. Eventually, as we witness more scientific advances in the RM field, there will be widespread use of RM therapies for tissue or organ repair.

Informants also discussed the timeframes involved for RM scientific progression and widespread venturing. The expected timeframes for taking RM science to market differs amongst the actors operating within the sector. VCs, SMEs and the UK government do not understand the timeframes involved in taking RM science to market, according to entrepreneurs and RM support entities. VCs, SMEs and the UK government expect a much quicker return on investment and as a consequence, this has serious implications for RM funding and, ultimately, commercialization. This is illustrated in example DD. A more reasonable timeframe for investors to see a return on their investment was suggested to be 10-30 years. In terms of scientific progressions, it was suggested that it could be 50 years before there is large-scale use of stem cells.

Table 3 here

Our data also highlights differences in the way in which each category of informant addresses the high levels of PEU and their approach to RM venturing. We have previously shown, in Table 2, the differences in the prevalence (\%) of each first-order code between all 4 categories of informants. To further illustrate the differences between categories and their approach to RM venturing, we highlight in Figure 2 the average occurrence (\%) of each theoretical dimension per informant category. This suggests the formation of two distinct lenses in informants' approach to RM venturing.

Lens 1 consists of entrepreneurs and RM support entities. Both approach venturing in a similar way and have similar perceptions of uncertainty, including the significance and effect of uncertainty. Both categories lack slack resources and place more emphasis on the venture 
development stage of the venturing model. They also both face similar PEU concerns, especially in relation to funding uncertainties. However, some differences are visible. For example, entrepreneurs appear to be relying on coping strategies less than any other category. Whilst further research is required in order to fully understand why this is the situation, we suggest that it is likely to be as a result of collaboration costs, which were evident within the dataset for the entrepreneur category.

Lens 2 consists of academics and support entities. They place a high emphasis on coping strategies, particularly collaborations, in addressing high levels of PEU. These collaborations progress scientific developments and improve current RM processes. Both categories are similarly concerned with the outcomes of RM venturing, especially in terms of innovation and economic development.

Figure 2 here

\section{Discussion}

Following the findings we present a RM venturing process model. Given the high levels of PEU surrounding RM venturing, we discuss alternative collaboration mechanisms. We extend the discussion to reflect on the effects of different coping strategies on resource assembly and collaborative knowledge. The effect of uncertainty on institutional culture is also considered.

\section{A process model of $\mathrm{RM}$ venturing}

Based on our findings we propose a RM venturing process model. This model is presented in Figure 3 and shows that high levels of PEU affect RM venturing. Also, since RM venturing is driven by university-led stem cell research, the entrepreneurial culture embedded within the university will determine successful RM venturing. In an attempt to overcome PEU and ensure 
successful venturing, RM ventures engage in coping strategies. Coping responses include collaborations and legitimacy building, which enables the assembly of resources and development of collaborative knowledge, resulting in venture formation and growth. As ventures continue to develop they may engage in further coping strategies, resulting in additional collaborative knowledge development. The final part of the model is the outcome of the venture, which may be a success and lead to economic gains, or it may be a failure.

Figure 3 here

\section{Collaboration under unresolved uncertainty}

Our findings indicate that entrepreneurs rely on coping strategies less than any other category. We have shown collaborative costs to exist during collaborations and highlighted unwilling collaborators. In addition, given the high levels of PEU, high partner uncertainty is expected. Under conditions of high collaboration costs, unwilling collaborators and high partner uncertainty, it is possible that RM entrepreneurs and new ventures rely on selective revealing as an alternative strategic mechanism to known collaboration mechanisms (Alexy et al, 2103). Through the selective revealing of knowledge, the focal collaborating firm attempts to induce the external collaborating firm to become more similar to them with respect to the production of knowledge. However, the use of selective revealing strategies in RM venturing may be problematic. If RM entrepreneurs and new ventures lack knowledge, or hold incorrect knowledge, we propose that the use of selective revealing in $\mathrm{RM}$ venturing will create collaborative networks of ignorance. This will have serious implications for the development of collaborative knowledge and venture outcome, since opportunity recognition depends on individuals mentally comparing new information with prior knowledge through a cognitive process of structural alignment (Grégoire et al, 2010). Therefore, if entrepreneurs or new 
ventures lack knowledge, or if incorrect knowledge has been selectively revealed, opportunity recognition will be affected.

\section{Coping strategies: resource assembly and collaborative knowledge}

Coping with uncertainty is a three-staged process. It involves primary appraisal in which individuals evaluate the threats to themselves. Secondary appraisal considers the response options available in order to deal with these threats. Coping with these threats relies on implementing the response options available and involves the use of two coping functions: a problem-focused coping and an emotion-focused coping (Lazarus and Folkman, 1984). During stressful situations individuals will utilize both types of coping functions in addressing the particular problem. However, problem-focused coping tends to predominate when individuals perceive that they can address the particular situation and emotion-focused coping prevails when the situation is less controllable (Folkman and Lazarus, 1980).

In this study we have shown that coping strategies include collaborations and legitimacy building. These depend on culture and uncertainty, and enable resource assembly and collaborative knowledge development. Such coping responses are examples of problem-focused coping strategies, as they reduce or remove the high levels of PEU. Several forms of problemfocused coping have been identified, such as specific interpersonal efforts to alter the stressful situation or the seeking of social support (Folkman et al, 1986b). The specific problem-focused coping form implemented by entrepreneurs is likely to have differing effects on resource assembly and collaborative knowledge development. For example, RM entrepreneurs implementing problem-focused coping, in which they seek social support, may find that they are unable to assemble resources and develop collaborative knowledge. This is because this form of coping relies on entrepreneurs obtaining external advice, assistance or knowledge. Yet, the 
potential existence of networks of ignorance is likely to result in access to incorrect advice, assistance or knowledge. This will have serious implications for venture outcomes.

Emotion-focused coping strategies enable entrepreneurs to manage their emotions in relation to the uncertainty and are most suited to uncontrollable situations. Therefore, they are especially valuable to entrepreneurs and ventures during RM venturing due to the high levels of unresolvable uncertainty surrounding RM. Several forms of emotion-focused coping strategies exist, which can facilitate or inhibit problem-focused coping. These include: wishful thinking, distancing, emphasizing the positive, self-blame, tension-reduction and self-isolation (Folkman et al, 1986a). Again, we can expect resource assembly and collaborative knowledge development to proceed differently depending on which form of emotion-focused coping is adopted. For example, entrepreneurs relying on wishful thinking may fail to see potential flaws in their business model or RM technology. If they then collaborate for resource assembly and knowledge development purposes, homophily effects suggest that the collaborating firm will also fail to see the potential flaws. This will have serious consequences on venture formation and growth. Similarly, entrepreneurs who rely on distancing themselves from the high levels of PEU, may fail to assemble resources and develop collaborative knowledge.

Individuals differ in their coping responses (Carver et al, 1989) and, therefore, resource assembly and collaborative knowledge development will vary. In this study we have shown that RM informant categories differ in their coping responses to high levels of PEU. As such, we reported two lenses, which consisted of entrepreneurs and ventures in one lens, and academic and support entities in another lens. This suggests that there is not an objectively "correct" interpretation of the best commercialization path. Unresolvable uncertainty and variations in the best commercialization path, may lead to the grouping of RM informants based on homophily effects. This may have serious implications for venture outcome, as groups will either randomly 
all succeed or fail based on whether their interpretation of the best commercialization path was accurate or not (Miner et al, 1996).

\section{Institutional culture}

RM venturing is driven by university-led stem cell research, which encourages venturing activity to be linked to university research and commercial outcomes. The embedded institutional culture and processes at the university and TTO are, therefore, likely to have an imprinting effect on the structure and characteristics of RM ventures which emanate from the university (Stinchcombe, 1965; Kimberly, 1975). At founding, new ventures are determined by the specific technological, economic, political and cultural resources that are available to them (Johnson, 2007). To ensure their survival and growth, they must follow strategies that are rewarded by their external environment (Kriaucinas and Kale, 2006). However, since RM ventures operate under extended periods of high levels of uncertainty, it is reasonable to suggest that imprinting effects will have unintended outcomes on the survival of young RM ventures. As such, imprinting effects, and also the inventing academic-entrepreneur's prior role-identity conflicts, presents significant challenges to RM venturing.

\section{Practical Implications}

Findings of this study present a novel picture of organizational coping under high levels of uncertainty. We suggest the need for entrepreneurs and new ventures to adopt coping strategies in response to the high levels of PEU, which can result in the development of collaborative knowledge and venture development. Entrepreneurs and new ventures, which fail to adhere to this, may find themselves unable to develop their business model. 
Our findings are also especially useful to TTOs, who are charged with: (1) preventing the improper use of inventions, (2) boosting financial returns from IP, and (3) generating social benefits from university research (Siegel et al, 2004). We recommend that universities and TTOs, which expect to commercialize their stem cell research, need to consider balancing their academic and commercialization culture. However, given the high uncertainties surrounding RM commercialization, the risk-aversive nature of TTOs and their focus on short-term cash maximization, commercialization of university-led RM research is still likely to be challenging (Phan and Siegel, 2006).

This research also has implications to UK government policymakers, who are not only charged with ensuring that the UK remains at the forefront of RM research, but also with the commercialization of this research. Our proposed RM venturing process model provides an important contribution in ensuring that the UK exploits the commercialization aspect of RM research.

\section{Limitations and Directions for Future Research}

In this study we examined RM venturing under high levels of PEU. We relied on informants recounting their involvement in RM venturing through a narrative process and as a result, we developed a RM venturing process model. Whilst the results of this study appear to be robust, the extent to which the RM process model is a true reflection of the RM venturing field, can only be confirmed through empirical analysis that tests specific hypotheses. The inductively derived theories of RM venturing proposed in this study also require further testing, refinement and development through further empirical research. There are also limitations inherent to our dataset, since it is primarily limited to RM venturing informants located in Scotland. Therefore, 
caution should be exercised in generalizing findings to other geographical or ecosystem boundaries. In addition, our dataset contains an overrepresentation of RM support entities.

Further empirical research is required to provide generalizable results of RM venturing. It would be especially useful to extend the small pilot survey to a large survey, which covers an international dataset. Furthermore, extension of interviews to other regions of the UK and internationally, is warranted.

We have suggested that RM entrepreneurs and ventures are relying on selective revealing. Further research is required to fully understand the existence and role of selective revealing in RM venturing, particularly the drivers and outcomes of this alternative form of collaboration mechanism. This is consistent with further research calls from Alexy et al (2013) and has the potential to reveal if RM ventures selectively reveal knowledge intentionally or unintentionally in order to shape the behavior of external actors.

We call upon further research to reveal the full nature of individual and organizational coping responses during opportunity exploitation and under high levels of PEU. This may distinguish which coping strategies are useful or detrimental in context. From this we can gain a deeper understanding of coping strategies for the assembly of resources, the development of collaborative knowledge and venture outcome. Our results emphasize the importance of research linking entrepreneurial cognition and decision-making to venture process, especially under high levels of uncertainty.

\section{Conclusions}

We investigated entrepreneurial activity within RM venturing, which is a sector characterized by unusually high levels of uncertainty. Our study advances theories of venture development by proposing a preliminary model linking uncertainty, collaboration and coping. 
We show that under high levels of PEU, entrepreneurs and RM ventures engage in coping strategies for venture development. Coping strategies address the high levels of uncertainty and the scarcity of resources, and include collaborations and legitimacy building. These assist resource assembly and drive collaborative knowledge development, leading to venture formation and growth. Furthermore, we have progressed the understanding of university-industry scholarship by showing the potential link between university culture and venture coping strategies. 


\section{Tables and Figures}

\section{Table 1. Study Informant Information}

\begin{tabular}{|c|c|c|c|c|}
\hline $\begin{array}{l}\text { Informant } \\
\text { number }\end{array}$ & Informant's role & Category & Organization type & $\begin{array}{c}\text { Organization } \\
\text { location }\end{array}$ \\
\hline 1 & $\begin{array}{l}\text { Director of } \\
\text { Operations }\end{array}$ & Support entity & Services & Edinburgh \\
\hline 2 & $\begin{array}{l}\text { Chief Executive } \\
\text { Officer and Founder }\end{array}$ & Entrepreneur & $\begin{array}{l}\text { Tools/Diagnostics/Services/Cell } \\
\text { Therapies }\end{array}$ & Glasgow \\
\hline 3 & $\begin{array}{l}\text { Business } \\
\text { Development } \\
\text { Manager }\end{array}$ & RM company & Services/Research & Edinburgh \\
\hline 4 & $\begin{array}{l}\text { Chief Executive } \\
\text { Officer and Founder }\end{array}$ & Entrepreneur & Services/Research/Consultancy & Edinburgh \\
\hline 5 & Academic scientist & Academic Scientist & Research & Edinburgh \\
\hline 6 & $\begin{array}{l}\text { Senior Economic } \\
\text { Development Officer }\end{array}$ & Support entity & Services & Edinburgh \\
\hline 7 & $\begin{array}{l}\text { Chief Executive } \\
\text { Officer }\end{array}$ & Support entity & Services & Edinburgh \\
\hline 8 & $\begin{array}{l}\text { Business } \\
\text { Development } \\
\text { Executive }\end{array}$ & Support entity & Research & Edinburgh \\
\hline 9 & $\begin{array}{l}\text { Director and } \\
\text { Academic }\end{array}$ & Academic scientist & Research & Edinburgh \\
\hline 10 & $\begin{array}{l}\text { Chief Executive } \\
\text { Officer and Founder }\end{array}$ & Entrepreneur & Cell Therapies/Services & Manchester \\
\hline 11 & $\begin{array}{l}\text { Industry Liaison } \\
\text { Manager }\end{array}$ & Support entity & Services & Glasgow \\
\hline 12 & Technology Manager & Support entity & Services & UK wide \\
\hline 13 & $\begin{array}{l}\text { Chief Executive } \\
\text { Officer and Founder }\end{array}$ & Entrepreneur & Tools/Diagnostics/Services/Research & Edinburgh \\
\hline 14 & $\begin{array}{l}\text { Chief Scientific } \\
\text { Officer and Founder }\end{array}$ & Entrepreneur & Services & Glasgow \\
\hline 15 & $\begin{array}{l}\text { Chief Executive } \\
\text { Officer }\end{array}$ & Support entity & Cell Therapies/Services/Research & London \\
\hline 16 & $\begin{array}{l}\text { Chief Executive } \\
\text { Officer }\end{array}$ & RM company & Tools/Diagnostics & Royston \\
\hline 17 & Outreach manager & Support entity & Services & Scotland \\
\hline 18 & $\begin{array}{l}\text { International Senior } \\
\text { Executive }\end{array}$ & Support entity & Services & Scotland \\
\hline 19 & Entrepreneur & Entrepreneur & Tools/Diagnostics & $\begin{array}{l}\text { Edinburgh/ } \\
\text { Glasgow }\end{array}$ \\
\hline 20 & $\begin{array}{l}\text { Chief Executive } \\
\text { Officer }\end{array}$ & Support entity & Services & Edinburgh \\
\hline 21 & $\begin{array}{l}\text { Head of Business } \\
\text { Development }\end{array}$ & Support entity & Services/Research & Edinburgh \\
\hline 22 & Academic scientist & Academic scientist & Research & Edinburgh \\
\hline 23 & $\begin{array}{l}\text { Head of Business } \\
\text { Creation }\end{array}$ & Support entity & Services/Research & Edinburgh \\
\hline
\end{tabular}


Table 2. Data Structure

\begin{tabular}{|c|c|c|c|c|c|c|c|}
\hline \multicolumn{5}{|c|}{$\begin{array}{l}\text { Prevalence in study } \\
\text { sample }(\%) *\end{array}$} & \multirow[t]{3}{*}{ First-Order Codes } & \multirow[t]{3}{*}{ Theoretical Categories } & \multirow[t]{3}{*}{ Theoretical Dimensions } \\
\hline \multicolumn{5}{|c|}{ Informant categories } & & & \\
\hline $\mathbf{T}$ & $\mathbf{E}$ & $\mathbf{A}$ & SE & RC & & & \\
\hline 61 & 83 & 67 & 50 & 50 & Risk & Types of uncertainty & Perceived \\
\hline 74 & 100 & 67 & 58 & 100 & Funding issues & & environmental \\
\hline 43 & 33 & 67 & 42 & 50 & $\begin{array}{l}\text { Manufacturing, scale-up } \\
\text { and distribution } \\
\text { uncertainty }\end{array}$ & & uncertainty (PEU) \\
\hline 39 & 50 & 0 & 42 & 50 & Regulatory uncertainty & & \\
\hline 17 & 17 & 33 & 17 & 0 & Scientific uncertainty & & \\
\hline 17 & 33 & 0 & 8 & 50 & Ethics & & \\
\hline 13 & 17 & 0 & 17 & 0 & $\begin{array}{l}\text { Reimbursement } \\
\text { uncertainty }\end{array}$ & & \\
\hline 39 & 17 & 33 & 58 & 0 & Academic conflicts & Inventing entrepreneurs & \multirow{4}{*}{$\begin{array}{l}\text { University } \\
\text { entrepreneurial culture }\end{array}$} \\
\hline 39 & 17 & 67 & 50 & 0 & Academic motivations & & \\
\hline 30 & 0 & 67 & 42 & 0 & Academic metrics & & \\
\hline 35 & 17 & 0 & 58 & 0 & $\begin{array}{l}\text { TTO business models and } \\
\text { processes }\end{array}$ & $\begin{array}{l}\text { TTO business models and } \\
\text { processes }\end{array}$ & \\
\hline 91 & 83 & 67 & 100 & 100 & $\begin{array}{l}\text { Collaborations with } \\
\text { industry }\end{array}$ & Collaborative partners & \multirow[t]{10}{*}{ Coping strategies } \\
\hline 74 & 33 & 100 & 83 & 100 & $\begin{array}{l}\text { Collaborations with } \\
\text { academia }\end{array}$ & & \\
\hline 39 & 17 & 33 & 50 & 50 & Collaborations with NHS & & \\
\hline 35 & 0 & 33 & 50 & 50 & $\begin{array}{l}\text { Collaborations with } \\
\text { support entities }\end{array}$ & & \\
\hline 39 & 67 & 67 & 17 & 50 & $\begin{array}{l}\text { Collaboration for sharing } \\
\text { of resources }\end{array}$ & Collaborative outcomes & \\
\hline 30 & 17 & 33 & 25 & 100 & $\begin{array}{l}\text { Collaboration for process } \\
\text { improvement }\end{array}$ & & \\
\hline 22 & 0 & 67 & 25 & 0 & $\begin{array}{l}\text { Collaboration for funding } \\
\text { purposes }\end{array}$ & & \\
\hline 9 & 17 & 33 & 0 & 0 & Collaboration costs & & \\
\hline 4 & 17 & 0 & 0 & 0 & $\begin{array}{l}\text { Collaboration for } \\
\text { legitimacy building }\end{array}$ & & \\
\hline 61 & 83 & 67 & 58 & 0 & Legitimacy building & Legitimacy building & \\
\hline 57 & 67 & 0 & 67 & 50 & Knowledge transfer & Resource exchange & \multirow{5}{*}{$\begin{array}{l}\text { Collaborative } \\
\text { knowledge }\end{array}$} \\
\hline 70 & 50 & 100 & 75 & 50 & Communication & mechanisms & \\
\hline 22 & 50 & 33 & 0 & 50 & Learning & & \\
\hline 26 & 17 & 33 & 33 & 0 & Language differences & & \\
\hline 57 & 50 & 33 & 75 & 0 & $\begin{array}{l}\text { RM and scientific } \\
\text { communities }\end{array}$ & Networks & \\
\hline 87 & 83 & 67 & 92 & 100 & Governmental funding & Funding sources & \multirow[t]{7}{*}{ Venture development } \\
\hline 61 & 83 & 33 & 58 & 50 & VC funding & & \\
\hline 35 & 0 & 100 & 33 & 50 & "Big pharma" funding & & \\
\hline 65 & 50 & 67 & 75 & 50 & $\begin{array}{l}\text { Spinout venture } \\
\text { formation }\end{array}$ & Spinout venture formation & \\
\hline 57 & 100 & 33 & 33 & 100 & Business models & Types of RM business & \\
\hline 9 & 33 & 0 & 0 & 0 & Integrated business model & models & \\
\hline 78 & 83 & 100 & 75 & 50 & Resources & Existing resources & \\
\hline
\end{tabular}




\begin{tabular}{|c|c|c|c|c|c|c|c|}
\hline 30 & 17 & 33 & 33 & 50 & Innovation & Economic development & Outcomes \\
\hline 30 & 0 & 0 & 58 & 0 & $\begin{array}{l}\text { Regional investment and } \\
\text { growth }\end{array}$ & & \\
\hline 65 & 67 & 67 & 58 & 100 & $\begin{array}{l}\text { Commercialization } \\
\text { timeframes }\end{array}$ & Future scenarios & \\
\hline 9 & 17 & 33 & 0 & 0 & $\begin{array}{l}\text { Potential industry } \\
\text { structure }\end{array}$ & & \\
\hline
\end{tabular}

* Does not account for multiple occurrences within a single interview. 


\section{Table 3. Illustrative evidence}

\begin{tabular}{|c|c|}
\hline Example & Quote \\
\hline $\mathrm{A}$ & $\begin{array}{l}\text { "... simply because trying to find funding, I mean, the other issue in all of this is that to undertake } \\
\text { anything is a hellish expensive process cause, I mean, we aren't even close to doing anything in terms of } \\
\text { going into clinical trials, and if you started that realm you're talking mega bucks, and therein lies the big } \\
\text { challenge for all of us." (CEO 1, support entity) }\end{array}$ \\
\hline B & $\begin{array}{l}\text { "And I think the industry is going to be moving to... call it different things: progressive licensing, } \\
\text { conditional approvals, expanded access, it's all moving towards this... and again and again the House of } \\
\text { Lords are talking about conditional approvals and asking people what they think of them, it's really clear } \\
\text { that that's going to be how the system moves in the future... So it's not just doing phase one, two, three, } \\
\text { get an approval and boom, start marketing. You're marketing it almost... not from day one, but once } \\
\text { you've got some efficacy, and it's a gradual increase in exposure to the patients." (Entrepreneur 3) }\end{array}$ \\
\hline $\mathrm{C}$ & $\begin{array}{l}\text { "The second sort of major group of problems are in what I'd call manufacturing and supply chain } \\
\text { issues...Lastly of course the major issue, how d'you get live cells to a patient or cells that are preserved } \\
\text { and delivered to a patient or tissues that have been grown and implied, so the entire business model, } \\
\text { manufacture and supply chain model is significantly different from what biotech and big pharma } \\
\text { understands as their business model." (CEO 2, support entity) }\end{array}$ \\
\hline $\mathrm{D}$ & $\begin{array}{l}\text { "...but you can see where this, you know, is the whole process going to be very much more localized } \\
\text { than you had with the pharmaceutical industry?" (Entrepreneur 3) }\end{array}$ \\
\hline $\mathrm{E}$ & $\begin{array}{l}\text { "The treatment of the patent regulations in Europe has also sort of blown things a bit in terms of people } \\
\text { saying 'well, how do you develop something if you can't protect it?' you know, that's something else." } \\
\text { (CEO 1, support entity) }\end{array}$ \\
\hline $\mathrm{F}$ & $\begin{array}{l}\text { "...now there's no way we're going to be doing clinical development on our own because we can't afford } \\
\text { to do it..." (Business Development Manager, RM company) }\end{array}$ \\
\hline G & “...reimbursement, that's the bit that's the missing piece at the moment.” (Entrepreneur 3) \\
\hline $\mathrm{H}$ & $\begin{array}{l}\text { "Ok, so Neil and I sat down and talked about it and we, we, we had enough money for about another } 6 \\
\text { months or something in the bank and we said we've got two choices; we can go find another processing } \\
\text { partner, we can repair the issue with this processing partner, which was only beginning to unfold at the } \\
\text { time, or we can do this ourselves, which we always wanted to do but were scared of the cost, the } \\
\text { implications, weren't sure if we'd get regulatory approval so that we could commission a lab and try and } \\
\text { raise money to do that, it's very difficult, it all a catch } 22 \text {, raising money is a whole big catch } 22 \ldots . . . \mathrm{em} \text {, } \\
\text { and, eh, so we took a decision to throw all the money at building a facility and doing it ourselves..." } \\
\text { (Entrepreneur 1) }\end{array}$ \\
\hline I & $\begin{array}{l}\text { "Well, so yes, so that's obviously a very difficult area because there's a tension here isn't there? I mean } \\
\text { academics as I've already said are judged by their papers and their grants...And, erm, spinouts take a lot } \\
\text { of time and a huge amount of work, erm, in terms of putting it all together and then a lot of time } \\
\text { promoting it and I think that group leaders find that extremely difficult because that's time that they're } \\
\text { not doing their academic work and ultimately they will be judged with the current metrics much more on } \\
\text { their academic work then they will on their commercialization work." (Academic scientist 2) }\end{array}$ \\
\hline $\mathrm{J}$ & $\begin{array}{l}\text { "I guess again that comes down to their tech transfer department to do that. Again, will they necessarily } \\
\text { understand? I don't think so?" (Director of Operations, support entity) }\end{array}$ \\
\hline K & $\begin{array}{l}\text { "...so we have access to the cell lines, or at least some of them, from [company name]." (Business } \\
\text { Development Manager, RM company) }\end{array}$ \\
\hline $\mathrm{L}$ & $\begin{array}{l}\text { "...the idea is that if we can work with them and take some of the processes and tune them up for proper } \\
\text { manufacturing." (CEO 2, support entity) }\end{array}$ \\
\hline M & $\begin{array}{l}\text { "Access to the NHS is very challenging in Scotland, very challenging indeed and companies often feel } \\
\text { that they would benefit - and they would benefit - from early conversations with the NHS where before } \\
\text { they design their medical device, they get input from the end users and that's really challenging... But } \\
\text { access to the NHS is something that comes up again and again and again, it's just something that's not } \\
\text { happened in Scotland." (Industry Liaison Manager, support entity) }\end{array}$ \\
\hline $\mathrm{N}$ & $\begin{array}{l}\text { "...our processing partner and the processing partner failed the regulatory inspection in a blaze of } \\
\text { glory... and the, em, the Human Tissue Authority, the regulator, suspended our human tissue authority } \\
\text { license..." (Entrepreneur 1) }\end{array}$ \\
\hline $\mathrm{O}$ & "...we had been talking to him, and talking to him, and talking to him, and he didn't, at first, believe that \\
\hline
\end{tabular}




\begin{tabular}{|c|c|}
\hline & $\begin{array}{l}\text { our technology did what it said it did because it is a paradigm shift for stem cell technology....and we get } \\
\text { a lot of people who don't believe it, although less and less. We are able to show people stuff now that } \\
\text { makes them realize that's it's the real deal..." (Entrepreneur 1) }\end{array}$ \\
\hline $\mathrm{P}$ & $\begin{array}{l}\text { "The other thing we managed to do is persuade, and this was the key I guess, was to persuade Scottish } \\
\text { Enterprise that it was in their interest or Scotland's interest in developing the regen medicine to help fund } \\
\text { the development of this capability...." (CEO 1, support entity) }\end{array}$ \\
\hline $\mathrm{Q}$ & $\begin{array}{l}\text { "...We've become active internationally as a mechanism of trying to demonstrate that UK is an attractive } \\
\text { place to do this sort of work in and then we'll partner with potential inward investors to either set up } \\
\text { manufacturing, you know, get clinical trials done, potentially being, if you like, the entry point into the } \\
\text { European arena through the UK." (CEO 2, support entity) }\end{array}$ \\
\hline $\mathrm{R}$ & $\begin{array}{l}\text { "...guess [we have] being able to convince people...they may look back and say 'right, who let those } \\
\text { idiots loose', I don't know [laugh] they may well say that now! But certainly at the time no, they were } \\
\text { fairly relaxed in terms of, if you like, 'trusting' that we knew what we were doing or what we'd like to } \\
\text { do." (CEO 1, support entity) }\end{array}$ \\
\hline $\mathrm{S}$ & $\begin{array}{l}\text { "I'm working, as I say, with [name of collaborator] and we are developing techniques which hopefully } \\
\text { will have commercial applications in the future. So it's kind of using my communication skills and } \\
\text { knowledge of embryology and his knowledge of transgenics and how that works." (Entrepreneur 2) }\end{array}$ \\
\hline $\mathrm{T}$ & $\begin{array}{l}\text { "...so there was a lot of work at that time about creating a network/a community which would almost act } \\
\text { as the kind of interpreter or teach the others at least some of the key words from their different languages } \\
\text { so they could at least understand each other when they were talking to each other." (Director of } \\
\text { Operations, support entity) }\end{array}$ \\
\hline $\mathrm{U}$ & $\begin{array}{l}\text { "... we had a knowledge transfer partnership with the university... and really that was used to sort of } \\
\text { develop our capability in creating cell lines that basically took on the form of hepatocytes." (Senior } \\
\text { Economic Development Officer, support entity) }\end{array}$ \\
\hline $\mathrm{V}$ & $\begin{array}{l}\text { "So I think, you know, first thing you've got to sit down with medics and properly discuss indication." } \\
\text { (Entrepreneur 3) }\end{array}$ \\
\hline $\mathrm{W}$ & $\begin{array}{l}\text { "The two communities are different aren't they... we speak a different jargon, speak a different } \\
\text { language." (Academic scientist 1) }\end{array}$ \\
\hline $\mathrm{X}$ & $\begin{array}{l}\text { "But I did talk to the people in advance and I think this is quite a good thing to do as well is to talk to the } \\
\text { TSB or whoever is awarding the grant that you're applying for and say 'look, we're thinking about doing } \\
\text { this sort of thing, should we give up already or is this worth doing?' and I was told it was worth doing." } \\
\text { (Business Development Manager, RM company) }\end{array}$ \\
\hline$Y$ & $\begin{array}{l}\text { "... because at the moment people in regen med talk about a funding gap and you'll hear this from many } \\
\text { people, but preclinical stuff... this kind of research and development that goes on in the university is } \\
\text { great, it's all academic. You then sort of do proof of concept stuff which is fundable because it's fairly } \\
\text { cheap, but then there's this clinical development which is extremely expensive and small companies can't } \\
\text { afford it, universities certainly can't afford it." (Business Development Manager, RM company) }\end{array}$ \\
\hline$Z$ & $\begin{array}{l}\text { "So all the funding that we get has to be matched and that's where a lot of people think that it's very easy } \\
\text { cause all these grants are available, but nobody's prepared to take a huge mortgage out to pay for it or to } \\
\text { pay the matching part because at the end of it they're not sure if they're going to get any money back." } \\
\text { (Entrepreneur 4) }\end{array}$ \\
\hline $\mathrm{AA}$ & $\begin{array}{l}\text { "The other part to it which actually to be honest never really materialized, we also thought there was the } \\
\text { opportunity of people actually utilizing our facilities to undertake that work, for them to actually come in } \\
\text { and do that work, a bit like a hotel. In reality that bluntly didn't happen for whatever reasons... what we } \\
\text { did with Cell Lab to some extent is move away... and started to moved away from a company that was... } \\
\text { you could argue was almost a service company to one that would eventually 'have product or products' } \\
\text { based on IP in one form or another, whether patented or not, that we could then market." (CEO 1, } \\
\text { support entity) }\end{array}$ \\
\hline BB & $\begin{array}{l}\text { "... so we now have Oristem available in } 6 \text { countries... Now alongside all of that we have digressed into } \\
\text { other products as well, so we have, em, actually got four products now. Oristem being the key } \\
\text { product... And then the final product, erm, is called Thallocell. But also we have two other therapies, em, } \\
\text { that we're working on as well. Em, one is an aesthetic medicine, so it's, em, cosmetics... So we would } \\
\text { hope to engage in a clinical trial in Hong Kong in the next } 6 \text { months, em, with proof of concept first, } \\
\text { kind of } 10 \text { people safety study...the cell type we have is ridiculously cool and, em, we have some } \\
\text { amazing technology and we're trying to do so much with it. And then we have another idea which is }\end{array}$ \\
\hline
\end{tabular}




\begin{tabular}{|c|c|}
\hline & around cardio, myocardio infarc." (Entrepreneur 1) \\
\hline $\mathrm{CC}$ & $\begin{array}{l}\text { "For renewable energy you can see windmills, you can see things going up, you can see things being } \\
\text { built, you can see jobs being created, in regenerative medicine you can't see that and the output you } \\
\text { would argue at the end of that might be that you're going to be using the current academic community, } \\
\text { the current clinical communities, so the same people, not particularly new jobs created which is what } \\
\text { they're all interested in; the output is when patients start getting better and the NHS costs go down." } \\
\text { (Director of Operations, support entity) }\end{array}$ \\
\hline $\mathrm{DD}$ & $\begin{array}{l}\text { "I think it's just that complete dyssynchrony between the timescales involved for this and the timescales } \\
\text { of most investors, even kind of public sector investors in this; they just can't wait that length of time and } \\
\text { I guess even if you get... what we're beginning to get the impression that kind of regenerative medicine } \\
\text { is beginning to lose its appeal even at Government level in Scotland now, just because there's nothing } \\
\text { you can see for it." (Director of Operations, support entity) }\end{array}$ \\
\hline
\end{tabular}


Figure 1. Informants' Level of Agreement with Particular Statements

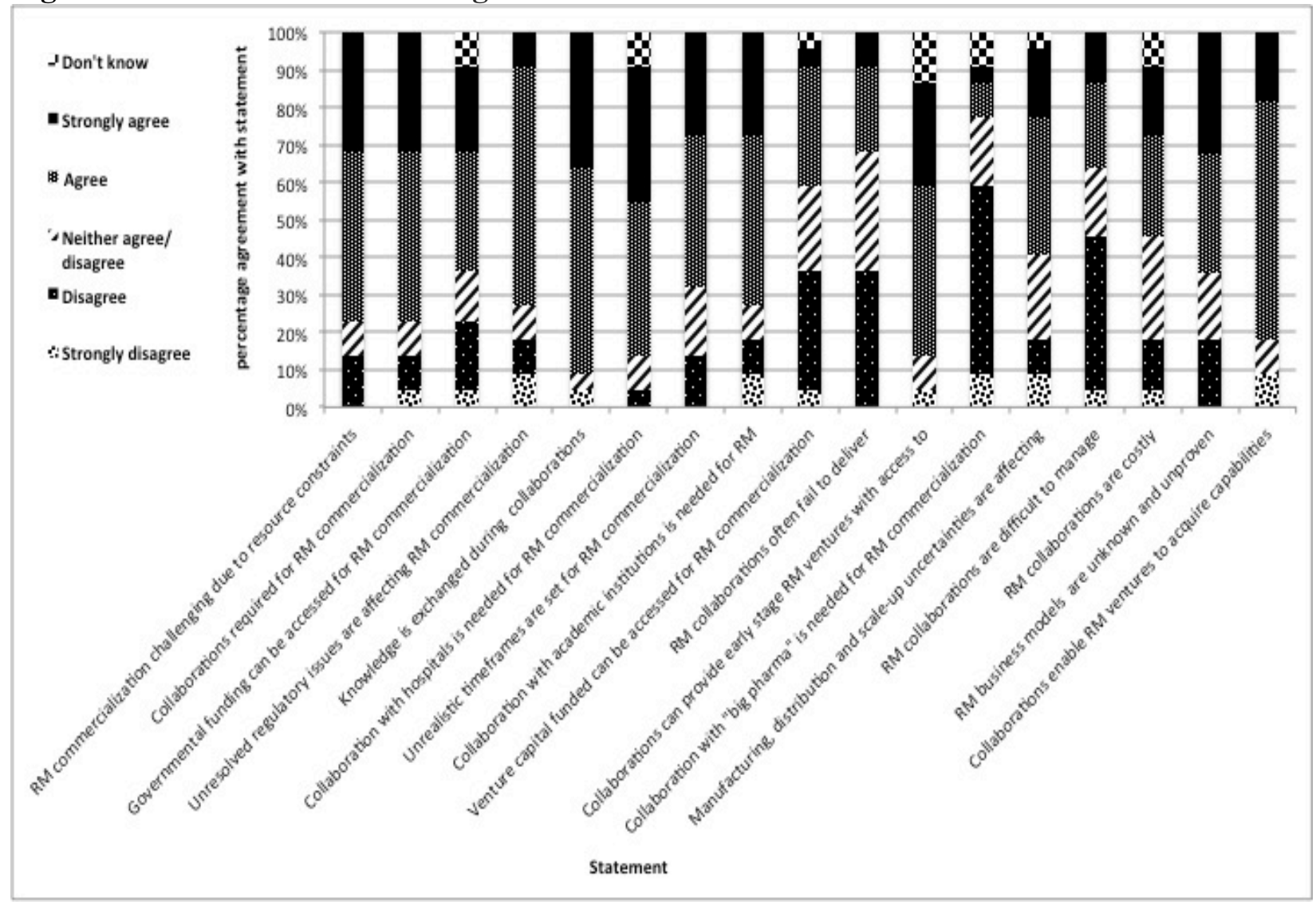


Figure 2. Revealed significance of uncertainty during narrative interview

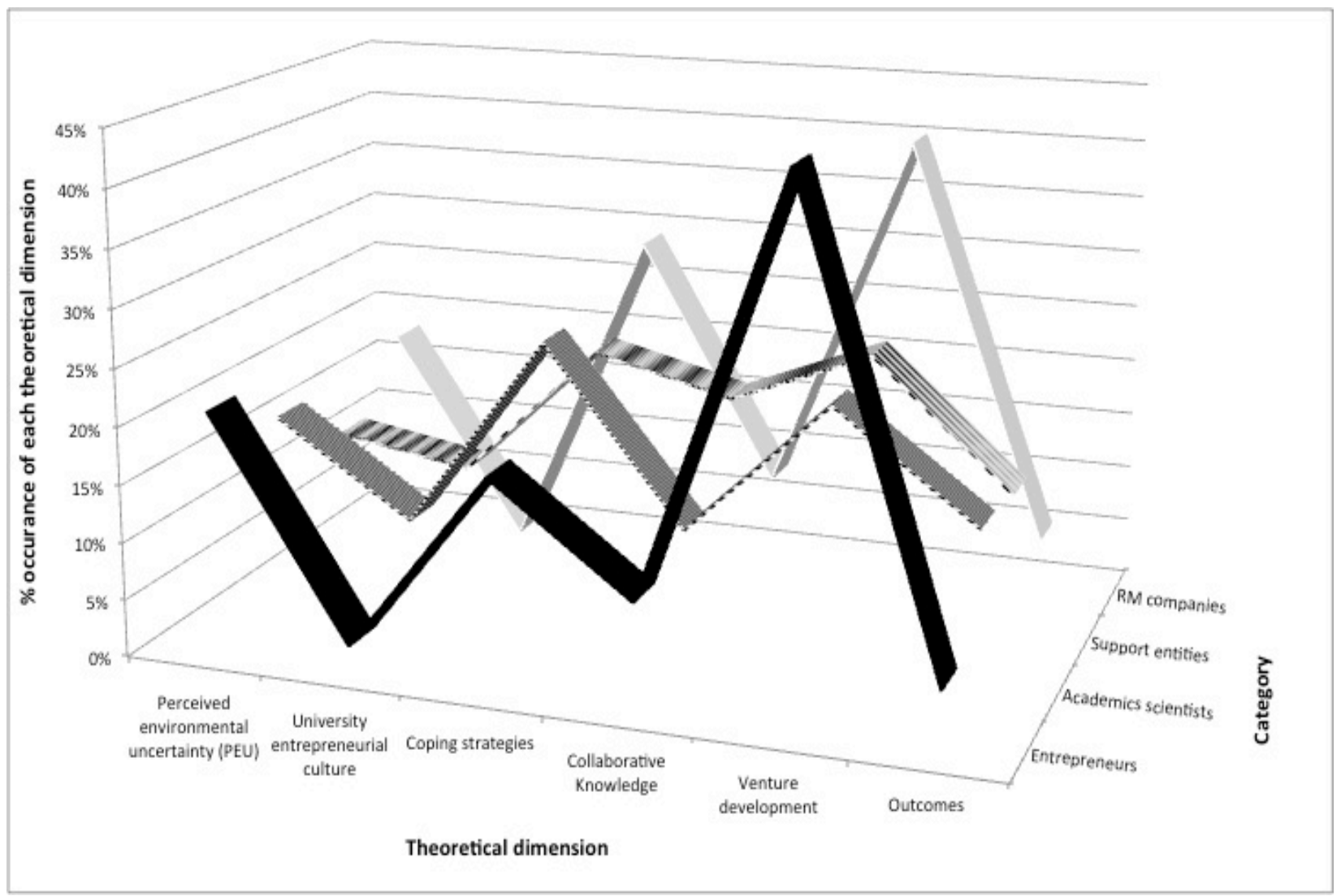


Figure 3. Process Model of RM Venturing

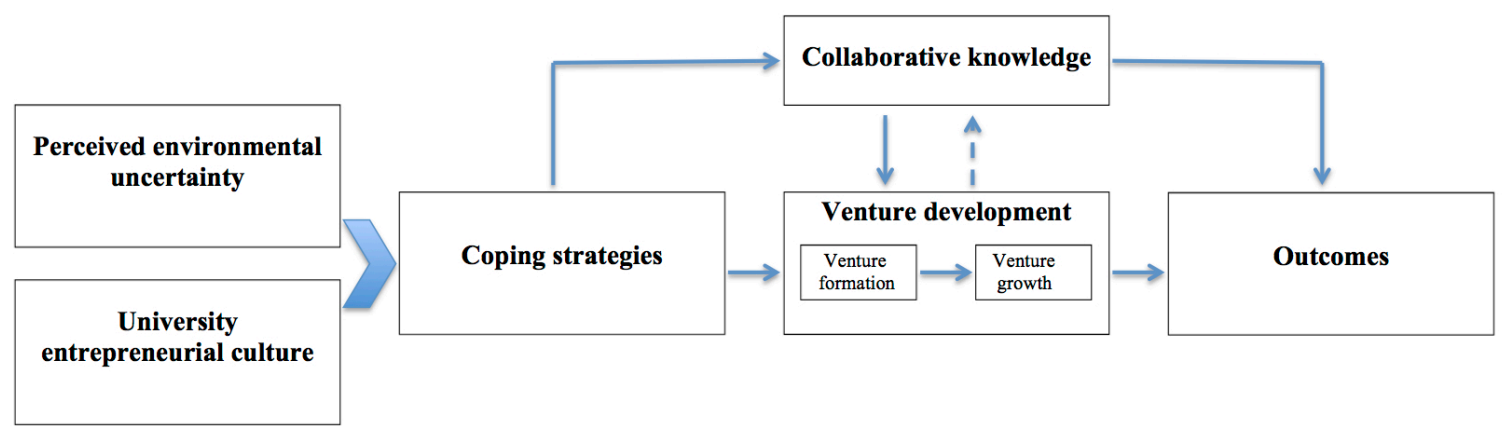




\section{Bibliography}

Aldrich, H.E. and Martinez, M.A. (2001) Many Are Called but Few Are Chosen: An Evolutionary Perspective for the Study of Entrepreneurship. Entrepreneurship, Theory and Practice, Vol. 25, No. 4, pp. 41-56.

Alexy, O., George, G. and Salter, A.J. (2013) Cui Bono? The Selective Revealing of Knowledge and its Implications for Innovative Activity. Academy of Management Review, Vol. 38, No. 2, pp. 270-291.

Alvarez, S.A. and Barney, J.B. (2005) How Do Entrepreneurs Organize Firms Under Uncertainty? Journal of Management, Vol. 31, No. 5, pp. 776-793.

Ardichvili, A., Cardozo, R.N., Tune, C. and Reinach, J. (2002) The Role of Angel Investors in the Assembly of Non-Financial Resources of New Ventures: Conceptual Framework and Empirical Evidence. Journal of Enterprising Culture, Vol. 10, No. 1, pp. 39-65.

Bock, A.J. (2012) Beyond the Magic Beanstalk: A Study of Life Science Ecosystem Formation at the University-Industry Boundary. Accessed on 09/03/13, http://www.businessschool.ed.ac.uk/_data/assets/pdf_file/0020/56207/120405-Bock

BeyondTheMagicBeanstalk2.pdf

Bock, A.J., Opsahl, T., George, G. and Gann, D.M. (2012) The Effects of Culture and Structure on Strategic Flexibility during Business Model Innovation. Journal of Management Studies, Vol. 49, No. 2, pp. 279-305.

Carver, C.S., Scheier, M.F. and Weintraub, J.K. (1989) Journal of Personality and Social Psychology, Vol. 56, No. 2, pp. 267-283.

Cassar, G. (2004) The Financing of Business Start-Ups. Journal of Business Venturing, Vol. 19, pp. 261-283.

Cohen, W.M. and Levinthal, D.A. (1990) Absorptive Capacity: A New Perspective on Learning and Innovation. Administrative Science Quarterly, Vol. 35, pp. 128-152.

Costa, S. and Levie, J. (2012) Business Model Change in Early-Stage Entrepreneurial Firms Facing High Levels of Uncertainty. Accessed on 18/03/13, https://www.strath.ac.uk/media/departments/huntercentre/research/workingpapers/Business _Models_Change in_Earlystage_Entrepreneurial_Firms_Facing_High_Uncertainty.pdf

Dacin, M.T., Goodstein, J. and Scott, W.R. (2002) Institutional Theory and Institutional Change: Introduction to the Special Research Forum. The Academy of Management Journal, Vol. 45, No. 1, pp. 43-56. 
Degroof, J. and Roberts, E. (2004) Spinning-off New Ventures from Academic Institutions in Areas with Weak Entrepreneurial Infrastructure: Insights on the Impact of Spin-off Policies on the Growth Orientation of Ventures. Journal of Technology Transfer, Vol. 29, pp. 327352.

Di Gregorio, D. and Shane, S. (2003) Why Do Some Universities Generate More Start-Ups Than Others? Research Policy, Vol. 33, pp. 209-227.

Etzkowitz, H. (1998) The Norms of Entrepreneurial Science: Cognitive Effects of the New University-Industry Linkages. Research Policy, Vol. 27, Issue 8, pp. 823-833.

Folkman, S. and Lazarus, R. (1980) An Analysis of Coping in a Middle-Aged Community Sample. Journal of Health and Social Behavior, Vol. 21, pp. 219-239.

Folkman, S., Lazarus, R., Dunkel-Schetter C., DeLongis, A. and Gruen, R.J. (1986a) Dynamics of Stressful Encounter: Cognitive Appraisal, Coping, and Encounter Outcomes. Journal of Personality and Social Psychology, Vol. 50, No. 5, pp. 992-1003.

Folkman, S., Lazarus, R., Gruen, R.J. and DeLongis, A. (1986b) Appraisal, Coping, Health Status and Psychological Symptoms. Journal of Personality and Social Psychology, Vol. 50, No. 3, pp. 571-579.

Fowler, F.J. (2009) Survey Research Methods, Fourth Edition. Sage Publications, London.

Friedman, J. and Silberman, J. (2003) University Technology Transfer: Do Incentives, Management, and Location Matter? Journal of Technology Transfer, Vol. 28, No. 1, pp. $81-85$.

George, G. (2005) Slack Resources and the Performance of Privately Held Firms. The Academy of Management Journal, Vol. 48, No. 4, pp. 661-676.

George, G. and Bock, A.J. (2012) Models of Opportunity. Cambridge University Press.

George, G., Kotha, R. and Zheny, Y. (2008) Entry into Insular Domains: A Longitudinal Study of Knowledge Structuration and Innovation in Biotechnology Firms. Journal of Management Studies, Vol. 45, No. 8, pp. 1448-1474.

Giebel, G. (2005) Stem Cells - A Hard Sell to Investors. Nature Biotechnology, Vol. 23, No. 7, pp. $798-800$.

Grégoire, D.A., Barr, P.S. and Shepherd, D.A. (2010) Cognitive Process of Opportunity Recognition: The Role of Structural Alignment. Organization Science, Vol. 21, No. 2, pp. $413-431$.

Heirman, A. and Clarysse, B. (2004) How and Why Do Research-Based Start-Ups Differ at Founding? A Resources-Based Configurational Perspective. Journal of Technology 
Transfer, Vol. 29, pp. 247-268.

Henrekson, M. and Rosenberg, N. (2001) Designing Efficient Institutions for Science-Based Entrepreneurship: Lessons from the US and Sweden. The Journal of Technology Transfer, Vol. 26, No. 3, pp. 207-231.

Hogle, L.F. (2014). Regenerative Medicine Ethics: Governing Research and Knowledge Practices. Springer: New York.

Jain, S. and George, G. (2007) Technology Transfer Offices as Institutional Entrepreneurs: The Case of Wisconsin Alumni Research Foundation and Human Embryonic Stem Cells. Industrial and Corporate Change, Vol. 16, No. 7, pp. 535-567.

Jain, S., George, G. and Maltarich, M. (2009) Academics or Entrepreneurs? Investigating Role Identity Modification of University Scientists Involved in Commercialization Activity. Research Policy, Vol. 38, pp. 992-935.

Jarillo, J. C. (1989). Entrepreneurship and Growth: The Strategic Use of External Resources. Journal of Business Venturing, Volume 4, Issue 2, pp. 133-147.

Jennifer, R. (2011) Taking Stock of Regenerative Medicine in the United Kingdom. Report by Office for Life Sciences, Department for Business Innovation and Skills.

Johnson, M.W., Christensen, C.M. and Kagermann, H. (2008) Reinventing your Business Model. Harvard Business Review, 86 (12), pp. 57-68.

Kimberly, J. (1975) Environmental Constraints and Organizational Structure: A Comparative Analysis of Rehabilitation Organisations. Administrative Science Quarterly, Vol. 20, pp. 19.

Kriauciunas, A. and Kale, P. (2006) The Impact of Socialist Imprinting and Search on Resource Change: A Study of Firms in Lithuania. Strategic Management Journal, Vol. 27, pp. 659679.

Lach, S. and Schankerman, M. (2004) Royalty Sharing and Technology Licensing in Universities. Journal of the European Economic Association, Vol. 2, No. 2-3, pp. 252-264.

Lazarus, R. and Folkman, S. (1984) Stress, Appraisal and Coping, Springer Publishing Company, New York.

Loch, C.H., Solt, M.E. and Bailey, E.M. (2008) Diagnosing Unforeseeable Uncertainty in a New Venture. The Journal of Product Innovation Management, Vol. 25, No.1, pp. 28-46.

Locke, K. (2001) Grounded Theory in Management Research. Sage Publications, London. 
Lockett, A. and Wright, M. (2005) Resources, Capabilities, Risk Capital and the Creation of University Spin-Out Companies. Research Policy, Vol. 34, Issue 7, pp. 1043-1057.

Lockett, A., Siegel, D., Wright, M. and Ensley, M.D. (2005) The Creation of Spin-Off Firms at Public Research Institutions: Managerial and Policy Implications. Research Policy, Vol. 34, pp. 981-993.

Lockett, A., Wright, M. and Franklin, S. (2003) Technology Transfer and Universities' Spin-Out Strategies. Small Business Economics, Vol. 20, pp. 185-200.

Lounsbury, M. and Glynn, M. A. (2001) Cultural Entrepreneurship: Stories, Legitimacy, and the Acquisition of Resources. Strategic Management Journal, Vol. 22, No. 6/7, pp. 545-564.

Martens, M.L., Jennings, J.E. and Jennings, P.D. (2007) Do the Stories They Tell Get Them the Money They Need? The Role of Entrepreneurial Narratives in Resource Acquisition. Academy of Management Journal, Vol. 50, No. 5, pp. 1107-1132.

Mastroeni, M., Mittra, J. and Tait, J. (2012) Realise Project: Methodology for the Analysis of Life Science Innovation Systems (ALSIS) and its Application to Three Case Studies. Accessed on 06/02/13, http://www.genomicsnetwork.ac.uk/media/REALISE\%20Case\%20Study\%20ReportInnogen.pdf.

McCracken, G. (1988) The Long Interview. Qualitative Research Series 13. London, UK: Sage Publications Ltd.

Milliken, F.J. (1987) Three Types of Perceived Uncertainty about the Environment: State, Effect, and Response Uncertainty. Academy of Management, Vol. 12, No. 1, pp. 133-143.

Miner, A., Devaughn, M. and Rura, T. (2001) The Magic Beanstalk Vision: Commercializing University Inventions and Research. In Schoohoven, C. and Romaneli, E. (Eds.) The Entrepreneurship Dynamic. Stanford University Press, Stanford, California.

Miner, A.S., Kim, J., Holzinger, I.W. and Haunschild, P. (1996) Fruits of Failure: Organizational Failure and Population Level Learning. Academy of Management Proceedings, August 1996, pp. 239-243.

Mittra J. and Tait J. (2012). New Business Models and Value Systems in Regenerative Medicine. MHRA Joint Workshop on the Regulation of UK Regenerative Medicine. October 30.

Morse, J.M., Barrett, M., Mayan, M., Olsne, K. and Spiers, J. (2002) Verification Strategies for Establishing Reliability and Validity in Qualitative Research. International Journal of Qualitative Methods, Vol. 1, No. 2, pp. 13-22.

Ndonzuau, F.N., Prinay, F. and Surelmont, B. (2002) A Stage Model of Academic $\quad$ SpinOff Creation. Technovation, Vol. 22, pp. 281-289. 
NIH, Regenerative Medicine Fact Sheet (2006). Accessed on 04/07/13, http://report.nih.gov/NIHfactsheets/Pdfs/RegenerativeMedicine(NIBIB).pdf

Phan, P.H. and Siegel, D.S. (2006) The Effectiveness of University Technology Transfer: Lessons Learned, Managerial and Policy Implications, and the Road Forward. Foundations and Trends in Entrepreneurship, Vol. 2, No. 2, pp. 77-144.

Plagnol, A.C., Rowley, E., Martin, P. and Livesey, F. (2009) Industry Perceptions of Barriers to Commercialization of Regenerative Medicine Products in the UK. Regenerative Medicine, Vol. 4, No. 4, pp. 549-559.

Podsakoff, P.M., MacKenzie, S.B., Lee, J.Y. and Podsakoff, N.P. (2003) Common Method Biases in Behavioural Research: A Critical Review of the Literature and Recommended Remedies. Journal of Applied Psychology, Vol. 88, No. 5, pp. 879-903.

Powell, W.W., Koput, K.W. and Smith-Doerr, L. (1996) Interorganizational Collaboration and the Locus of Innovation: Networks of Learning in Biotechnology. Administrative Science Quarterly, Vol. 41, No. 1, pp. 116-145.

Renault, C.S. (2006) Academic Capitalism and University Incentives for Faculty Entrepreneurship. Journal of Technology Transfer, Vol. 31, No. 2, pp. 227-239.

Scott, W. R. (2001) Institutions and Organizations, Second Edition. Sage Publications, Thousand Oaks, California.

Siegel, D.S., Waldman, D.A., Atwater, L. E. and Link A.N. (2004) Toward a Model of the Effective Transfer of Scientific Knowledge from Academicians to Practitioners: Qualitative Evidence from the Commercialization of University Technologies. Journal of Engineering and Technology Management, Vol. 21, pp. 115-142.

Stinchcombe, A.L. (1965) Social Structure and Organizations. In March, J.G. (Ed.), Handbook of Organizations, pp. 142-193. Rand McNally, Chicago, IL.

Strauss, A. and Corbin, J. (1990) Basics of Qualitative Research: Grounded Theory Procedures and Techniques. Sage Publications, London.

Tait, J., Bruce, K., Courtney, A., Gregson, G., Lowrie, H., Mastroeni, M., Mittra, J., Peasron, M.A., Robertson, M. and Snowden, K. (2011) Business Models and Value Systems for Regenerative Medicine Therapies: Rationale and Methodology. Accessed on 28/09/12, http://www.genomicsnetwork.ac.uk/media/REALISE\%20Case\%20Study\%20ReportInnogen.pdf.

Thursby, J.G. and Kemp, S. (2002) Growth and Product Efficiency of University Intellectual Property Licensing. Research Policy, Vol. 31, pp. 109-124. 
Walsh, I.J. and Bartunek, J.M. (2011) Cheating the Fates: Organizational Foundings in the Wake of Demise. Academy of Management Journal, Vol. 54, No. 5, pp. 1017-1044.

Zahra, S.A. and George, G. (2002) Absorptive Capacity: A Review, Reconceptualization, and Extension. Academy of Management, Vol. 27, pp. 185-203. 